\section{STERILISATION OF MILK BY ELECTRICITY.}

\section{To the Editor of THE LANCET.}

SIR,-In the annotation under this title in your issue of this date there are one or two slight errors which in fairness to others I must ask you to contradict. The work was being done in the Thompson Yates Laboratories when I was appointed to Liverpool. I did not initiate the work, but at the request of the Health Committee of the city I reported on what had been done, suggested further experiments, and in conjunction with Mr. F. C. Lewis, who had carried out the original work, made various alterations in apparatus and methods. Throughout the work Mr. Lewis has been intimately associated with me, and the reports published are joint reports. I feel that it is unfair that credit should be given to me for work which could not have been undertaken and which certainly would never have been brought to a successful issue had I not had the valuable assistance and hearty coöperation of Mr. Lewis. I am, sir, yours faithfully,

University of Liverpool, May 8 th, $1920 . \quad$ J. M. BEATTIE.

\section{LICE AS A CAUSE OF RINGWORM.} To the Editor of THE LANCET.

SIR,-The letter of Dr. A. E. L. Wear in your issue of May 1st, on the relationship of lice to ringworm, reminds me of an occurrence which happened nigh 40 years ago. On that occasion a patient showed me her forearm, on which there was a well-marked circle of ringworm about the size of a threepenny-piece. When told the nature of the ailment, she asked if it could have been brought to her by a flea, for some four days previously, when serving in her shop, she felt herself bitten at the exact spot at which the ringworm had appeared, but not caring to ascertain at the moment what had taken place, had contented herself with rubbing the part smartly through her sleeve. When the customer had gone, she had turned up her cuff, and "out sprung the flea." I told her that there could be little doubt the flea had brought the disease, and that the vigorous rubbing had implanted it at the bitten part. I made a note of the matter as a curiosity, but failed to grasp its significance, although the fact and its explanation were alike offered to me.

I am, Sir, yours faithfully,

J. ALLAN GRAY, M.A., M.D., F.R.C.P. Edin.

Leith, May 3rd, 1920

\section{THE DEATH OF DR. A. P. SPELMAN : A MOVING APPEAL.}

To the Editor of THE LANCET.

SIR,-I take the liberty of appealing to you on behalf of the widow and children of the late Dr. A. P. Spelman, of Dunmore, Co. Galway. Last week, when returning from a call, his motor-car skidded at a badly protected part of the road, and, overturning, killed him instantly. The deceased was only 26 years of age, and had not his life insured in any way.

Mrs. Spelman and two young children are now left absolutely destitute and totally unprovided for, and in these circumstances I would appeal to your readers for their help.

Thanking you in anticipation,

I am, Sir, yours faithfully, P. J. DeLANEY, M.B.

Claremorris, Co. Mayo, May 4th, 1920.

PS.-We are circularising all the local doctors. Subscriptions, which will be duly acknowledged, may be sent to myself or Dr. T. A. Heneghan, Ballindine, Co. Mayo.

Lyme Regis Cottage Hospital.-It is proposed to erect a new cottage hospital at Lyme Regis. The building will contain accommodation for six male and six female patients. There will also be a children's ward, two private wards, operatins theatre, and an $\mathrm{X}$ ray room. The site has been purchased, the plans prepared, and the chairman of the hospital has issued a strong appeal for financia support.

\section{itleoiral âdos.}

Society OF APOTHECARIES of London.-At examinations held recently the following candidates passed' in the subjects indicated :-

Surycry-G. S. Ashby (Sect. I.), King's Coll. Hosp.; C. C. Bennett (Sect. I.), Guy's Hosp.; A. G. L. Brown (Sects. I. and II.), West minster Hosp, ; A. Furniss (Sect. IL.), Manchester; M. Ibrahim (Sects. I. and II.), Middlesex Hosp.; and A. L. Urquhart Sects. I. and Ir.), Edinburgh.

Medicine.-R. E. Laurent (Sect. I.), Westminster Hosp.; M. Pigott (Sects. I. and II.), Manchester; and A. I. Urquhart (Sects. I. and II.), Edinburgh.

Forensic Medicine,-E. Brazao, Middlesex Hosp.: J. A. Cohen, King's Coll. Hosy.; M. Pigott, Manchester; and A. L. Urquhart, Edinburgh.

Midwifery.-E. Brazao, Middlesex Hosp.; J. A. Cohen, King's Coll. Hosp.; A. McKenzie, Guy's Hosp.; M. Pigott, Manchester R. M. Rodriguez, Barcelona ; W. H. Summerskill, Guy's Hosp and A. L. Urouhart, Edinburgh.

The Diploma of the Society was granted to the following candidates entitling them to practise medicine, surgery, and midwifery:M. Ibrahim, M. Pigott, and A. L. Urouhart.

The Whitsun Congrés DE MÉdecrNe aT BRUSSELS.-The Association of French-speaking Doctors is holding its fourteenth congress from Wednesday, May 19th, to Saturday, the 22nd, in the Palais des Académies at Brussels, under the presidency of Dr. Henrijean, professor of medicine at Liége, with whom are associated Professor Bordet and Professor Vandervelde (vice-presidents), and Professor René Verhoogen (secretary-general). The opening ceremony takes. place on Wednesday at 4 P.M. The morning sessions commence at 9 A.M. on each following day, being devoted to (Thursday) Cardio-vascular Syphilis, (Friday) the Lipoids in Pathology, and (Saturday) the Therapeutic Value of Artificial Pneumothorax. The afternoon sessions at 4 P.M. are devoted to more general topics, such as the Social Campaign Against Syphilis, the Coagulation of the Blood, and Heredity. On Sunday an excursion to the Yser front and the Flanders coast is in prospect. Further information from the secretarygeneral, 22 rue Joseph II., Brussels.

University of Manchester ApPeaL: "The King's. SEVENTY." -The fertility of ideas and seductive processes evolved to bring grist to the educational mill of the University of Manchester bring also new surprises almost daily. The latest proposal is that 70 towns or districts or firms should be found, each of which should undertake to raise $£ 5000$ to swell the fund and crown the $£ 500,000$ required. These to be called "The King's Seventy." The idea has taken root and already two shoots have appeared. The Mayor of Blackpool has intimated to H.M. the King that Blackpool will raise $£ 5000$ and Crompton, a much smaller urban district, has intimated that it also will guarantee to raise an equal sum. The star on the barometer-ladder outside the University now stands at $\$ 184,000$. The Manchester Guardian on May 7 th issued an interesting illustrated supplement in aid of the same object. It contains, amongst other matters, a message from the Chancellor, Viscount Morley, who says: "It [a good university] is one of the keys and clues for that progress towards. making a democracy from which there is nothing to fear and everything to hope." Viscount Haldane discourses on "The Mission of the Civic University," Sir Henry A. Miers on "The University and the Community," and Viscount Bryce on "The Function of a Modern University."

Venereal Disease Clinics and Professional SECRECY. - A deputation from the London and Counties Medical Protection Society, Ltd., was received by Dr. Addison at the Ministry of Health on May 6th. The deputation was introduced to the Minister of Health by LieutenantColonel F. E. Fremantle, M.P., and the chairman of the London and Counties Medical Protection Society (Dr. C. MI. Fegen), on behalf of the deputation, urged upon the Minister of Health the necessity for early legislation to protect the medical officers of venereal disease clinics from being compelled in the witness-box to violate the established principles of professional secrecy, and to give information of the nature of their patients' ailments and of anything else which came to their knowledge in their professional capacity. The medical officers of venereal clinics, he said, were being compelled in the law courts, under penalty of imprisonment for contempt of court, to reveal what their patients had communicated to them, believing that the information would be treated as absolutely confidential. The effect of this, it was pointed out, would be disastrous to the working of the venereal disease clinics, and would militate with fatal effect against the present efforts being made to cure and eliminate venereal disease. The Minister of Health expressed his cordial agreement with the views of the deputation, and promised to do what he could to promote legislation as suggested by the deputation. He said that he felt sure that public opinion would support the maintenance of professional secrecy in connexion with venereal disease clinics. 